\title{
Substrate-related differences in antipredator behaviour of two gobiid fish species and the brown shrimp, and their adaptive value
}

\author{
Bo Tallmark \& Sverker Evans
}

Department of Zoology, Uppsala University, Box 561, S-751 22 Uppsala, Sweden

\begin{abstract}
Factors affecting the predator-related mortality of sand goby Pomatoschistus minutus (Pallas), common goby P. microps (Krøyer) and brown shrimp Crangon Crangon L. were investigated in Gullmar Fjord, Sweden. Substrate selection and locomotory activity was recorded in the 3 species on sand and on mud. Sand goby and brown shrimp preferred sand to mud, while common goby preferred mud to sand. Activity was clearly correlated to substrate type. In all 3 species, swimming activity was increased by a factor 4 when kept on the less preferred substrate. Predation experiments were performed with sand or mud as bottom substrate and with cod as predator. On sand, common gobies were more rapidly eliminated by the predator than were sand gobies, and sand gobies more rapidly than brown shrimps. On mud, sand gobies were more rapidly taken than were common gobies and brown shrimps. Staying on the 'wrong' substrate will result in increased locomotory activity which will in turn increase the risk of predation. We suggest that the microgeographical distribution of members of the epibenthic guild is primarily a consequence of various behaviour patterns. Predators act to restrict the habitat use of these fish and shrimp species. Differences in behaviour between the species when encountering a predator reduce their vulnerability to predators on their respective preferred substrate. This may in part explain the spatial segregation and will contribute to the maintainance of community structure.
\end{abstract}

\section{INTRODUCTION}

Selective predation by fish has been demonstrated to influence community structure in marine and freshwater ecosystems (e.g. Brooks \& Dodson 1965, Wells 1970, Dodson 1974, Nelson 1979, Stoner 1979). Predators may control microdistribution of prey not only through selective elimination but also through intimidation (Charnov et al. 1976). Many studies have dealt with the foraging strategies of the predator (for reviews see Curio 1976, Macan 1977), but considerably fewer have specifically dealt with the antipredator behaviour of the prey.

In the marine, shallow soft-bottom environment, the presence of vegetation increases habitat complexity and reduces predator-related mortality for small fish and crustaceans (Nelson 1979, Stoner 1979, Berglund \& Bengtsson 1981, Coen et al. 1981, Heck \& Thoman 1981, Minello \& Zimmerman 1983). On bare sand, on the other hand, shelter is lacking and the risk of predation might be one of the many factors that limit the habitat use of epibenthic species. Various antipredator behaviours developed by potential prey species are of great survival value and contribute to the segregation of species occupying different substrates.

On the Swedish west coast the dominant species of the epibenthic guild on unvegetated bottoms are the sand goby Pomatoschistus minutus (Pallas), the common goby P. microps (Krøyer) and the brown shrimp Crangon crangon L. (Evans \& Tallmark 1979, 1984, 1985). Generally, sand goby and brown shrimp are dominant on sandy bottoms whereas common goby is most abundant on muddy bottoms. All 3 species show a wide overlap in dietary habits and only a small temporal segregation in peak abundances. This will make it possible for them to exploit resources available when one of them temporarily is reduced in number or even absent (Evans \& Tallmark 1985). Our previous results indicated that interference competition, where space is the proximate object of competition, is important in maintaining both structure and size of the epibenthic guild. In this paper we evaluate the role of behaviour and predation in small-sized fish and shrimp species on shallow bottoms, and concentrate on the following 
questions: (1) Does the substrate affect the predation rate of these species? (2) Are there any differences in antipredator behaviour between these species, and if so, are they substrate dependent? (3) Is there a correlation between the antipredator behaviour of these small-sized fish and shrimp species and the predation pressure?

\section{MATERIAL AND METHODS}

Experiments were conducted at Klubban Biological Station in Gullmar Fjord, Swedish west coast $\left(58^{\circ} 15^{\prime} \mathrm{N}, 11^{\circ} 28^{\prime} \mathrm{E}\right)$. Animals and bottom material were collected in Kvarnbukten and Kilviken Bays, located in the vicinity of the station. Kvarnbukten Bay is moderately exposed and contains clean sand. The dominant epifaunal species are brown shrimp and sand goby. Kilviken Bay is very sheltered, also sandy but with a high content of silt in the substrate. Common goby and brown shrimp are common there. The physical features and epifauna in the 2 bays have been described previously (Evans \& Tallmark 1985). The main differences between the substrates were found in the silt-clay fraction (Kilviken $14 \%$, Kvarnbukten $3 \%$ ) and in the organic content 13.5 and $0.3 \%$ D. W., respectively). From each site surficial bottom substrate used in the experiments was collected and sieved through $1 \mathrm{~mm}$ mesh. Fishes and shrimps were collected with a small hand trawl net.

Predation experiments. Two outdoor tanks with a bottom area of $2.4 \mathrm{~m}^{2}$ and water depth of $70 \mathrm{~cm}$ were provided with running water. The bottoms of the 2 tanks were covered with a 4 to $5 \mathrm{~cm}$ thick substrate layer, 1 tank with sand from Kvarnbukten Bay and the other with silty sand from Kilviken Bay. Cod Gadus morrhua of 15 to $35 \mathrm{~cm}$ length were caught in fyke nets and were kept $\geqslant 3 \mathrm{~d}$ in aquaria without food. Ten sand gobies and 10 brown shrimps from Kvarnbukten Bay, and 10 common gobies from Kilviken Bay, were put into each tank. One to $2 \mathrm{~h}$ later $1 \mathrm{cod}$ was added to each tank. Ten to $12 \mathrm{~h}$ later the cod were removed. Their stomach contents were identified, the tanks were refilled to the original composition of prey animals and a new cod was added a few hours later.

Once a week the tanks were emptied and fresh substrate and test animals were added. A test with bullheads (Cottus spp.) as a predator was also performed. The experiments ran from May to July. In May the sand gobies were 4 to $6 \mathrm{~cm}$ in length and the common gobies $3.4 \mathrm{~cm}$. In July a new group of sand goby of 2.5 to $3.5 \mathrm{~cm}$ arrived, while there were still adult common gobies of 3.5 to $4.5 \mathrm{~cm}$ size. The brown shrimps tested were $3.5 \mathrm{~cm}$ long throughout the period.

Behavioural experiments. Substrate selection was tested in aquaria with a bottom area of $0.1 \mathrm{~m}^{2}$ where one half of the bottom was covered with sand and the other with mud. The 3 species were tested separately. Two specimens of each species were put together into the aquaria in each test. Every $15 \mathrm{~min}$ the positions of the animals were recorded and specimens were exchanged every hour. Tests were also made in outdoor tanks ( $1 \mathrm{~m}^{2}$ bottom area) with 10 sand gobies and 10 common gobies in every run.

The activity of the animals was recorded in aquaria with sand or mud, respectively. Activity was defined in terms of number of animals swimming, lying on or burrowed in the substrate. Their positions were recorded for $30 \mathrm{~s}$ once every hour. Each species was tested separately, using 5 specimens at a time.

The escape distance for the 2 goby species on sand and on mud was tested using a dummy fish predator moved slowly toward the prey.

\section{RESULTS}

\section{Predation}

Predation on sand and on mud was quite different for all 3 species (Fig. 1). On sand, common gobies were more rapidly tracked down and eliminated by cod than were sand gobies $(\mathrm{z}=-4.86, \mathrm{p}<0.001)$, which in turn were more rapidly taken than were brown shrimps ( $z=-3.25, p<0.001$ : Wilcoxon matched-pairs signedranks test; Siegel 1956). On mud, sand gobies were more rapidly eaten than were common gobies and brown shrimps $(z=-4.02$ and $-3.73, p<0.001$ for both). Similar results were obtained in a few experiments using bullheads as predator. There was no difference in the proportions of the 2 gobiid species taken

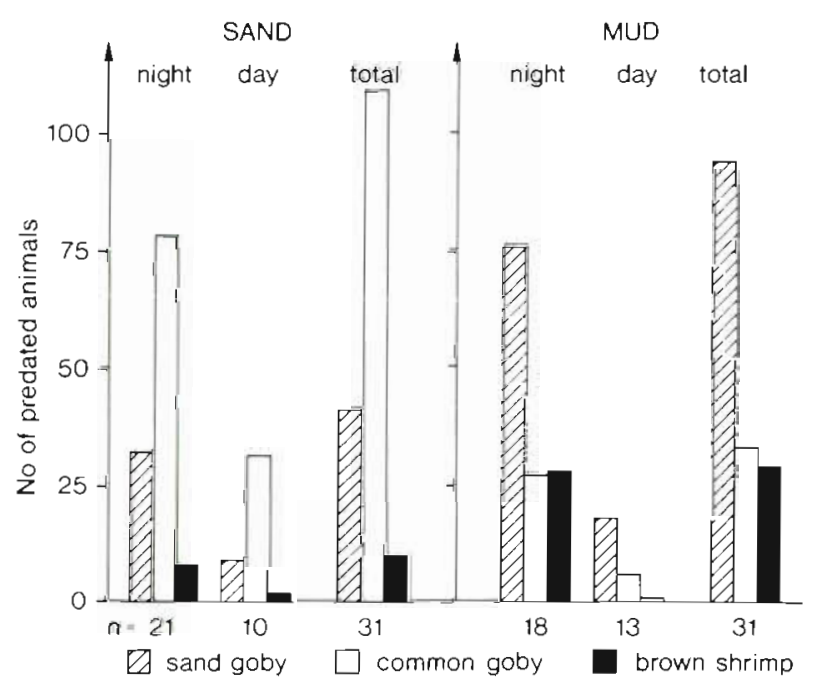

Fig. 1. Selective predation by cod on sand goby, common goby and brown shrimp on sand and mud. $\mathrm{n}=$ number of test runs 
Table 1. Substrate selection in sand goby, common goby and brown shrimp. Percentage distribution of animals on sand and mud respectively

\begin{tabular}{|c|c|c|c|c|c|}
\hline & \multicolumn{2}{|c|}{ Distribution $(\%)$} & \multirow[t]{2}{*}{ No. of test } & \multirow[b]{3}{*}{$x^{2}=8.84$} & \multirow{5}{*}{$\begin{array}{l}p<0.05 \\
p<0.001 \\
p<0.01\end{array}$} \\
\hline & On mud & On sand & & & \\
\hline Sand goby & 45 & 55 & \multirow{3}{*}{$\begin{array}{l}684 \\
570\end{array}$} & & \\
\hline Common goby & 66 & 34 & & \multirow[t]{2}{*}{$x^{2}=60.69$} & \\
\hline Brown shrimp ${ }^{1}$ & 39 & 61 & & & \\
\hline${ }^{1}$ Data from Erik & & & & & \\
\hline
\end{tabular}

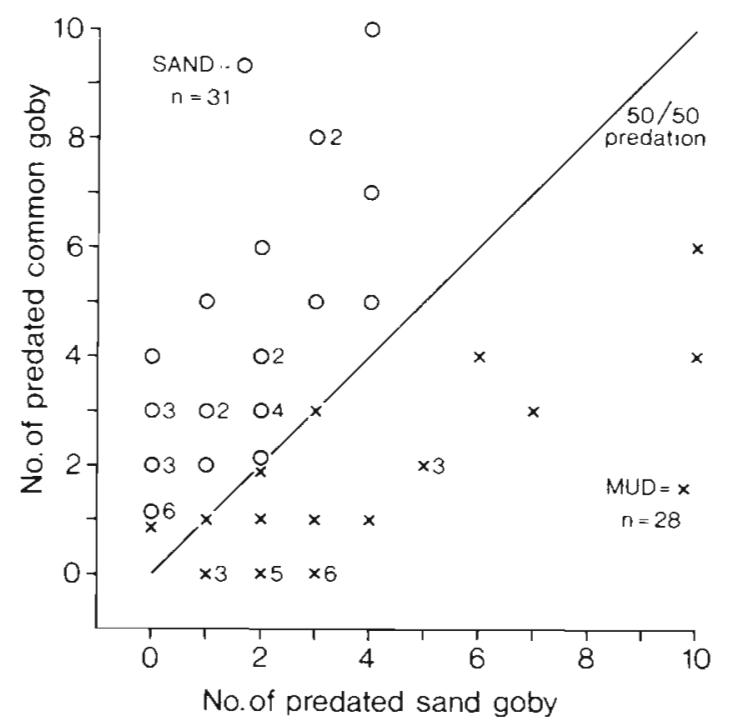

Fig. 2. Predation of sand goby and common goby on sand and mud. Ten specimens of each species per run

by the predator when the predator consumed only a few and when it consumed several prey items (Fig. 2). All 3 species were taken by the predator more readily at night than in the day (Fig. 1): sand goby $\chi^{2}=20.81$, $p<0.001$; common goby $\chi^{2}=40.68, p<0.001$; brown shrimp $\chi^{2}=9.26, p<0.01$. However, the same proportion of predation between the species appeared also during daytime. In only 10 tests out of 70 were specimens of all 3 species consumed.

Small cod (15 to $25 \mathrm{~cm}$ ) consumed an average of 6 prey per $12 \mathrm{~h}$, while larger cod $(26$ to $33 \mathrm{~cm})$ consumed only 3 . This was probably due to the size of the tanks, which were too small for larger cod to be maximally effective as hunters.

\section{Behaviour}

All 3 prey species are highly capable of changing their colour and of rapidly camouflaging themselves by mimicking the colour of the bottom. Brown shrimp has the greatest capacity for burrowing, both in sand and in mud. The common goby was the species that burrowed most in mud while the sand goby seldom burrowed in any substrate.

Generally, all 3 prey species had a preference for a particular substrate (Table 1). Sand goby and brown shrimp preferred sand to mud, while common goby preferred mud to sand. The 2 gobiids were also tested in large tanks $(1 \times 1 \mathrm{~m})$ using 10 specimens at a time. Here their substrate preferences were still more pronounced $\left(\chi^{2}, p<0.001\right.$ for both species).

The escape reactions of the 3 species were quite different (Fig. 3). Sand goby dashed away 30 to $60 \mathrm{~cm}$ in one long leap and then touched the bottom, but did not burrow. Both common goby and brown shrimp fled shorter distances moving in series of zig-zag leaps and finally burrowing. In all 3 species, escape patterns were independent of the substrate. The flight distance from a dummy fish predator was somewhat longer for sand goby than for common goby, both on sand and on mud (Table 2). Brown shrimp remained immobile even longer than the 2 gobies when approached by the dummy fish predator.

Locomotory activity was clearly correlated to substrate type (Table 3). In all 3 species, activity was increased by about a factor 4 when kept on their less preferred substrate. In sand goby, $25 \%$ of the specimens were swimming above the muddy surface compared to only $6 \%$ over sand. Brown shrimp also showed an increased swimming activity on mud. In the common goby, on the other hand, only $6 \%$ were swimming above the muddy substrate in comparison to

Table 2. Escape distances in sand goby and common goby measured as the distance from a fish dummy. Means $\pm \mathrm{SD}$ from 40 tests

\begin{tabular}{|lll|}
\hline & \multicolumn{2}{c|}{ Escape distance $(\mathrm{cm})$} \\
& Mud & Sand \\
\hline Sand goby & $8.5 \pm 2.8$ & $8.6 \pm 3.9$ \\
Common goby & $6.6 \pm 1.7$ & $6.4 \pm 2.3$ \\
& $\mathrm{t}=2.89$ & $\mathrm{t}=3.73$ \\
& $\mathrm{P}<0.001$ & $\mathrm{P}<0.001$ \\
\hline
\end{tabular}




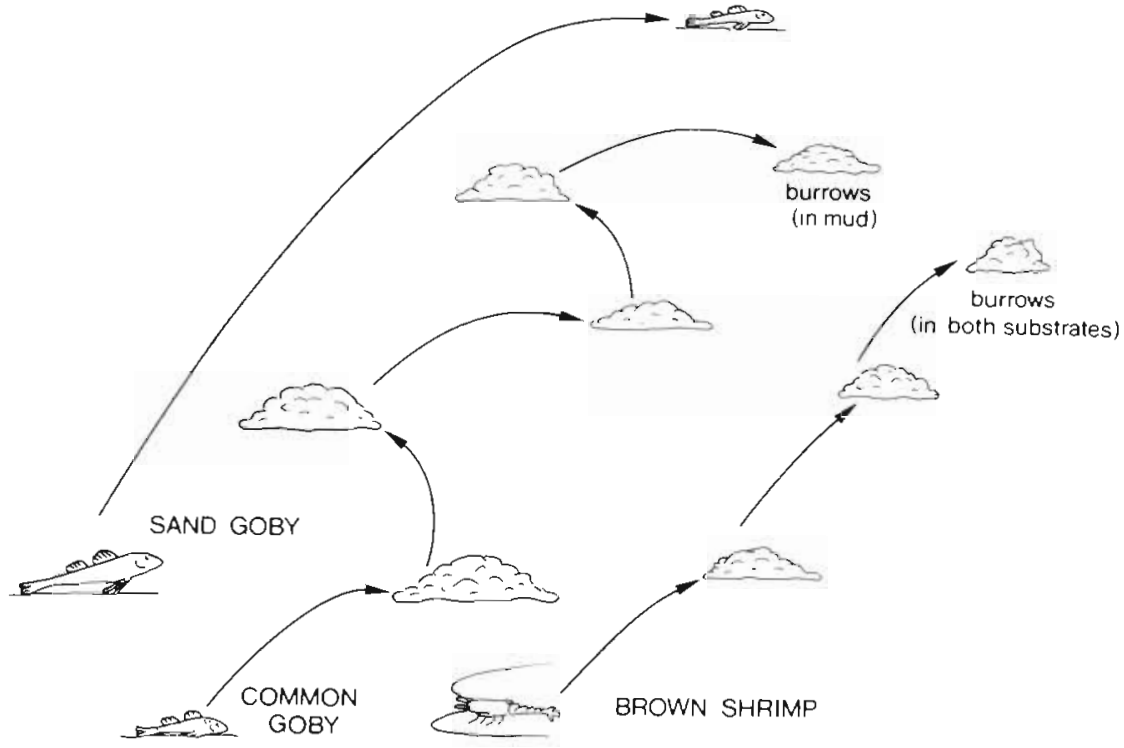

Fig. 3. Escape behaviour patterns of sand goby, common goby, and brown shrimp For explanation see text

Table 3. Locomotory activity in sand goby, common goby and brown shrimp on mud and sand. Total number of occurrences of each activity in 40 tests, 5 specimens per test $\chi^{2}, p<0.001$ for mud and sand for all 3 species

\begin{tabular}{|lccc|}
\hline & \multicolumn{3}{c|}{ Locomotory activity } \\
& Swimming & On bottom & Burrowed \\
\hline Mud & & & \\
Sand goby & 51 & 149 & 0 \\
Common goby & 13 & 150 & 37 \\
Brown shrimp & 16 & 158 & 26 \\
Sand & & & \\
Sand goby & 12 & 188 & 0 \\
Commongoby & 59 & 141 & 0 \\
Brown shrimp & 4 & 143 & 53 \\
\hline
\end{tabular}

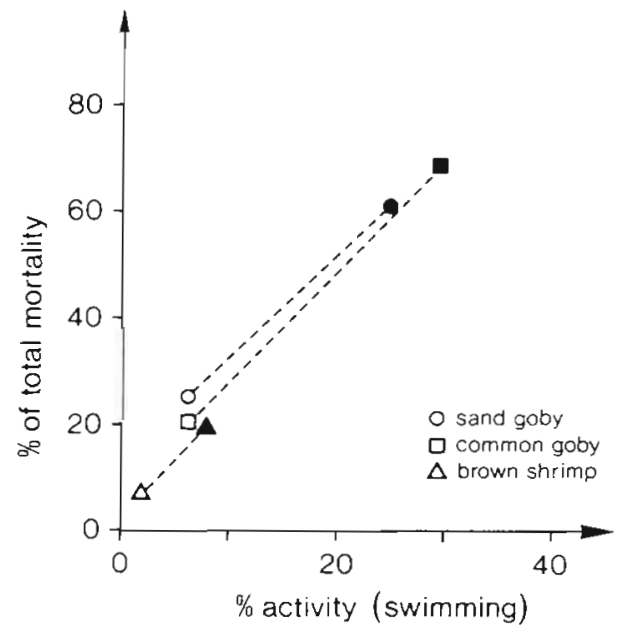

Fig. 4. Relation between locomotory activity (see Table 4) and mortality (see Fig. 1) on sand and mud. Open symbols: preferred substrate; filled symbols: less preferred substrate
$29 \%$ over sand. In the predation experiments, mortality rates of all 3 species were directly proportional to their swimming activity, which in turn was related to the type of substrate (Fig. 4). Movement of the prey was the main trigger mechanism releasing the attacking behaviour of both cod and bullhead. However, the attacks were very often unsuccessful.

\section{DISCUSSION}

The results of our previous studies (Evans \& Tallmark 1979, 1984, 1985) demonstrated the existence of a certain spatial segregation of small-sized epibenthic fish and shrimp species in shallow water. Brown shrimp and sand goby are abundant on sandy bottorns while common goby is abundant in silty habitats. However, this distribution is by no means absolute; at reduced abundances the different fish and shrimp species may invade each other's core habitats so that the total abundance of individuals in the guild remains fairly constant. A central question examined in our present paper is the relation of prey-species behaviour to predation pressure. Several investigations have shown that the risk of predation is often a function of exposure, which is related, among other things, to the structural complexity of the habitat (Smith 1961, Macan 1966, Schutz 1969, Ware 1972, Gilinsky 1984). Sandy and unvegetated bottoms should provide only partial protection, compared with silty and vegetated ones, and the risk of predation therefore ought to be higher. However, behavioural adaptations in brown shrimp and sand goby may reduce their vulnerability in the open habitat. In fact, predators and prey may often persist in natural communities because adaptive 
improvements in one call forth an adaptive response in the other, and as long as this process of mutual adaptation can continue, prey and predator can coexist.

Prey movement is an essential criterion of prey perception by visual predators. Ware (1973) produced experimental evidence for the importance of prey movement in increasing predation rates by rainbow trout. Our results indicate that the rate of predation on small-sized fish and shrimp species may be expressed as a linear function of prey mobility. Potential prey benefit by selecting a substrate where predation pressure is lower and where presumably the probability of survival is greater.

The mobility of the prey species will affect the success of predators attacking gobies and shrimps. When approached by a predator, both goby species and brown shrimp often exhibited irregular and unpredictable behaviour. This behaviour has been shown to reduce the predator's success (Humphries \& Driver 1967, 1970, Driver \& Humphries 1970). In addition, the stirring up of loose bottom substrate by common goby and brown shrimp may also be an effective escape mechanism. The sand goby, on the other hand, dashes away in one long leap and then rests upon the substrate, but seldom burrows. This behaviour ought to be more effective on sand where refuges are rare and where no stirring up of mud will mislead the predator. A dash and subsequent cessation of movement of a prey organism has also been shown to be effective against predation among fishes (McPhail 1969, Neill 1970).

A close coincidence of the activity rhythm of the predator with that of its prey allows for a high rate of encounter between them and therefore will enhance predation. Predation by larger fish in very shallow water occurs mainly during night, while both sand goby and common goby are active during daytime (Wiederholm, pers. comm.). The total number of eaten prey animals varied irregularly between 0 and 18 individuals per $12 \mathrm{~h}$.

The differences in behaviour between the species when encountering a predator have evolved because they are effective in reducing vulnerability to predators on the respective preferred substrate (Table 4). Prey animals often seek microhabitats with reduced predatory risk, referred to as resource depressions (Charnov et al. 1976, Stein \& Magnuson 1976, Stein 1977. Orth 1977). Selection will act to enforce the association of epibenthic prey animals with their specific microhabitats. Staying on the 'wrong' substrate will demand increased locomotory activity which will further increase the risk of predation. This may in part explain the observed spatial segregation arid will contribute to the maintenance of community structure.

Acknowledgements. We thank G. Gezelius, J. Gray, S. Thorman and S. Ulfstrand for their helpful comments on the manuscript. We also thank C. Carlsson, R. Dufva, T. Elofsson, B. Falk, S. Holm and L. Rogberg for technical support.

\section{LITERATURE CITED}

Berglund, A., Bengtsson, J. (1981). Biotic and abiotic factors determining the distribution of two prawn species: Palaemon adspersus and P. squilla. Oecologia (Berl.) 49: 300-304

Brooks, J. L., Dodson, S. J. (1965). Predation, body size and composition of plankton. Science 150: 29-35

Charnov, E. L., Orians, G. H., Hyatt, K. (1976). Ecological implications of resource depression. Am. Nat. 110: $247-259$

Coen, L. D., Heck, K. L., Abele, L. G. (1981). Experiments on competition and predation among shrimps of seagrass meadows. Ecology 62: 1484-1493

Curio, E. (1976). The ethology of predation. Zoophysiology and ecology. Vol. 7. Springer, Berlin, Heidelberg \& New York

rable 4. Relative differences in the behaviour in sand goby, common goby and brown shrimp on sand and mud, and their outcome

\begin{tabular}{|llll|}
\hline Parameter & Sand goby & Common goby & Brown shrimp \\
\hline Visibility $^{1}$ & & & $>$ \\
Escape reaction $^{1}$ & One long leap & Short zig-zag leaps & Short leaps \\
Escape distance $^{1}$ & & Mostly on mud & Common \\
Burrowing behaviour & & Sand \\
Preferred substrate & Rare & Mud & Sand \\
Highest abundance in the field ${ }^{2}$ & Sand & Sand & Mud \\
Outcome & & Sand & Mud \\
Highest locomotory activity & Mud & Sand & Mud \\
Highest mortality & Mud & & \\
${ }^{1}$ No differences on sand and mud & & & \\
2 Evans \& Tallmark 1985 & & & \\
\hline
\end{tabular}


Dodson, S. J. (1974). Zooplankton competition and predation: an experimental test of the size efficiency hypotheses. Ecology 55: 605-613

Driver, P. M. Humphries, D. A. (1970). Protean displays as inducers of conflict. Nature, Lond. 226: 968-969

Eriksson, S., Evans, S., Tallmark, B. (1975). On the coexistence of scavengers on shallow, sandy bottoms in Gullmar Fjord (Sweden): Adaptations to substratum, temperature and salinity. Zoon. 3: 65-70

Evans, S., Tallmark, B. (1979). A modified drop-net method for sampling mobile epifauna on marine shallow sandy bottoms. Holarct. Ecol. 2: 58-64

Evans, S., Tallmark, B. (1984). Seasonal dynamics of small vagile predators on a marine shallow soft bottom. Holarct. Ecol. 7: 138-148

Evans, S., Tallmark, B. (1985). Niche separation within the mobile predator guild on marine shallow soft bottoms. Mar. Ecol. Prog. Ser. 23: 279-286

Gilinsky, E. (1984). The role of fish predation and spatial heterogeneity in determining benthic community structure. Ecology 65: 455-468

Heck, K. L., Thoman, T. A. (1981). Experiments on predatorprey interactions in vegetated aquatic habitats. J. exp. mar. Biol. Ecol. 53: 125-134

Humphries, D. A., Driver, P. M. (1967). Erratic displays as a device against predators. Science 156: 1767-1768

Humphries, D. A., Driver, P. M. (1970). Protean defence by prey animals. Oecologia (Berl.) 5: 285-302

Macan, T. T (1966). Predation by Salmo trutta in a moorland fishpond. Verh. int. Verein. theor, angew. Limnol. 16: $1081-1087$

Macan, T. T. (1977). The influence of predation on the composition of freshwater animal communities. Biol. Rev. 52: $45-70$

McPhail, J. D. (1969). Predation and the evolution of a stickleback. J. Fish. Res. Bd Can. 26: 3183-3208

Minello, T. J., Zimmerman, R. J. (1983). Fish predation on juvenile brown shrimp penaeus aztecus Ives: the effect of simulated Spartina structure on predation rates. J. exp. mar. Biol. Ecol. 72: 211-231

Neill, S. R. St. J. (1970). A study of antipredator adaptations in fish with special reference to silvery camouflage and shoaling. Ph. D. thesis, Oxford Univ.

Nelson, W. G. (1979). Experimental studies of selective predation by amphipods: consequences for amphipod distribution and abundance. J. exp. mar. Biol. Ecol. 38: 225-245

Orth, R. J. (1977). The importance of sediment stability in seagrass communities. In: Coull, B. C. (ed.) Ecology of marine benthos. Univ. South Carolina Press, Columbia, p. $281-300$

Schutz, D. C. (1969). An experimental study of the feeding behaviour and interaction of coastal cutthroat trout (Salmo clarhi clarhi) and dolly warden (Salvelinus malma) M. Sc. thesis. Univ. of British Columbia

Siegel, S. (1956). Nonparametric statistics for the behavioural sciences. McGraw-Hill, Aukland

Smith, M. W. (1961). Bottom fauna in a fertilized natural lake and its utilization by trout (Salvelinus fontinalis) Verh. int. Verein theor. angew. Limnol. 14: 722-726

Stein, R. A., Magnuson, J. J. (1976). Behavioural response of crayfish to a fish predator. Ecology $57: 751-761$

Stein, R. A. (1977). Selective predation, optimal foraging, and the predator-prey interaction between fish and crayfish. Ecology 58: $1237-1253$

Stoner, A. W. (1979). Species-specific predation on amphipod crustacea by the pinfish Lagodon rhomboides: mediation by macrophyte standing crop. Mar. Biol. 55: 201-207

Ware, D. M. (1972). Predation by rainbow trout (Salmo gairdneri): the influence of hunger, prey density and prey size. J. Fish. Res. Bd Can. 29: 1193-1201

Ware, D. M. (1973). Risk of epibenthic prey to predation by rainbow trout (Salmo gairdneri). J. Fish. Res. Bd Can. 30: $787-797$

Wells, L. (1970). Effects of alewife predation on zooplankton populations in Lake Michigan. Limnol. Oceanogr. 15: 556-565

This article was presented by Professor J. Gray; it was accepted for printing on November 29, 1985 